\title{
World Plastic Surgery Day, July 15: Sānubandhen Jèvitah (Through Continuity [It] Lives)
}

Dinesh Kadam

${ }^{1}$ Department of Plastic and Reconstructive Surgery, A J Institute of Medical Sciences and Research Centre, Mangalore, Karnataka, India

Indian J Plast Surg 2021;54:101-102.

Sānubandhen Jèvitah: "Sāh anubandhen jèvitah" (through continuity [it] lives) (In Sanskrit)

The ancient Indian surgeon Sushruta (700-600 BC) originally described the value of pedicle for the viability of flaps. He utilized pedicle-based cheek flaps, " Sānubandhen Jèvitah," to reconstruct the nose and ears. ${ }^{1}$ This fundamental understanding paved the way for modern-day reconstructive surgery. In the present context, India, the Land of Sushruta, is taking a lead role as Sānubandhen Jèvitah in propagating the "World Plastic Surgery Day" from this year onwards.

India celebrates the National Day of Plastic and Reconstructive Surgery every July 15 . After a decade of successful implementation, now July 15 marks World Plastic Surgery Day. In a recently held American Society of Plastic Surgery (ASPS) Global Summit of 34 national plastic surgery societies, the proposal was introduced by the APSI President Prof. R.K. Khazanchi. Responding to our president's solicitation, the ASPS has pronounced July 15 as the 'World Plastic Surgery Day.' This is indeed a privilege for Indian counterparts who have taken the initiative from the outset. A global day is an excellent opportunity for the international plastic surgery community to come together on a single platform, speak with one voice, and address common issues; to be a springboard for awareness-raising actions.

\section{National Plastic and Reconstructive Surgery Day}

In 2011, the then President of APSI, Dr. Raja Sabapathy, mooted this innovative idea and launched National Plastic and Reconstructive Surgery Day. ${ }^{2}$ The objective was to generate public awareness about the specialty by conducting various activities together on a specific day and drawing society's attention. The response and support to Dr. Sabapathy's

DOI https://doi.org/ $10.1055 / \mathrm{s}-0041-1732779$ ISSN 0970-0358
Address for correspondence Dr. Dinesh Kadam MS, DNB, MCh, Professor and Head, Department of Plastic and Reconstructive Surgery, A I Institute of Medical Sciences and Research Centre, Mangalore-575004, Karnataka, India

(e-mail: drkadam@yahoo.co.in).

call were instant, comprehensive, and nationwide. Everyone enthusiastically participated and uniquely contributed to the purpose. Individual surgeons, teaching departments, state and regional associations, and the APSI held various programs to connect masses and educate them. Many conducted free surgeries, public awareness programs, street shows, walkathons, lectures, write-ups in print and social media, and more. The opportunity has been well utilized to organize activities related to the different fields of plastic surgery and showcase them to the public at large.

The day also marks the $2^{\text {nd }}$ anniversary of the all-new print version of the IJPS under Thieme Publishers released on July 15, 2019, at AIIMS Delhi by the Director, Prof Randeep Guleria ( - Fig. 1). The event was followed by an interactive session with the media by Dr. Amresh Baliarsingh, APSI president, Dr. RK Khazanchi, Vice President, along with AIIMS faculty, which received wide coverage.

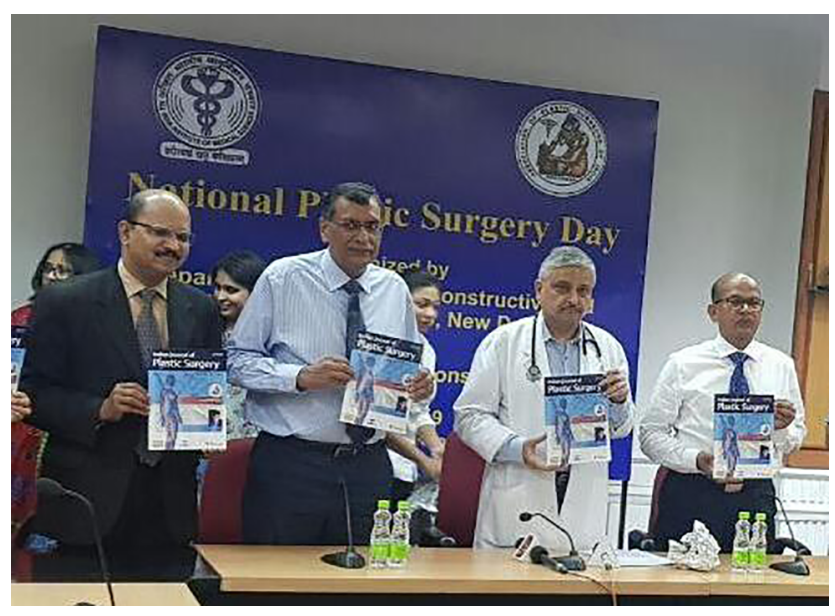

Fig. 1 Release of IJPS new print edition in 2019 at AlIMS, Delhi.
(C) 2021. Association of Plastic Surgeons of India.

This is an open access article published by Thieme under the terms of the Creative Commons Attribution-NonDerivative-NonCommercial-License, permitting copying and reproduction so long as the original work is given appropriate credit. Contents may not be used for commercial purposes, or adapted, remixed, transformed or built upon. (https://creativecommons.org/licenses/by-nc-nd/4.0/).

Thieme Medical and Scientific Publishers Pvt. Ltd. A-12, 2nd Floor, Sector 2, Noida-201301 UP, India 
Events at various places across the country have created a domino effect for a positive change over the years. What was achieved collectively with one voice on a national scale has been an unmeasured success. Yet, there is much to be desired, considering the diverse socioeconomic, demographic, and linguistic challenges besides inadequacies in the healthcare system. The specialty remains poorly understood and riddled with misconceptions among the people due to various barriers, even to date. Unfortunately, medical practitioners and the medicos are no exceptions. The true understanding of the specialty among the medical students is missing. Introduction in the undergraduate curriculum, rotation postings will help get an orientation and evoke interest to pursue later.

As an association, we need to design a multipronged strategy to engage with the general public, the medical fraternity, and social influencers and reach out to the corridors of powers to affect desired results. With coordinated and sustained efforts, each of us, as an individual could bring about tremendous change to demonstrate the utility and spectrum of plastic surgery and facilitate the needy access proper health care.

Surgeons with subspecialty interests, such as hand surgery, aesthetic surgery, cleft \& craniomaxillofacial surgery, burns, microsurgery,and vascular surgery have a crucial role in promoting and integrating the highly diverse sections of plastic surgery. As much public perception and awareness, the scientific publications and academic interactions with a specific peer group of different specialties of common interests are essential.

With ongoing covid pandemic and restrictions, we will miss holding events to mark celebrations this year as well. However, this opens up another opportunity to utilize and communicate effectively through social media, ${ }^{3}$ with 3.5 billion users worldwide. The APSI conducted a comprehensive webinar for the general public in 2020, and more such events from different corners are desired.

\section{Global Day Strategy}

Globally over 45,000 plastic surgeons form a formidable community in the health care system. There are common issues, aspirations, and challenges that require collaborative efforts and strategies among international peers. Besides providing healthcare, the progress of specialty, collaborative research, and training are pertinent.

Plastic surgeons are crucial to reducing the global burden of surgical diseases, preventing death and disability by restoring form and function. Of the 44 essential procedures listed in the publication of World Bank's Disease Control Priorities, the plastic surgery procedures include treatment of injuries, burns, and congenital malformations. ${ }^{4}$ However, plastic surgery services across the world are woefully lacking. Five out of the 7.4 billion population do not have access to reconstructive surgeons. ${ }^{5}$ The burden is considerably huge in low- and middle-income countries (LMICs), lacking expertise and safe and appropriate medical access. The role of high-income countries supplementing the capacity building for LMICs to match the global standard is now the focus. With the international outreach approach, many areas such as burns, cleft, and craniofacial surgery have achieved sustainable long-term collaborative care. ${ }^{6}$

The International Confederation of Plastic Surgery Societies (ICOPLAST), an international collaborative body, aimed to address the growing issues affecting all plastic surgeons.? With over 25,000 members from 66 countries, ICOPLAST needs to play a significant role in promoting this day. The July 15 is non-controversial and does not endorse any place, country, or historical event nor coincides with any notable event. $^{2}$

Online interactions during the current pandemic have virtually erased frontiers and distances and enabled the free flow of knowledge. It should help the entire international plastic surgeons as a community and meet the challenges faced by them. World Plastic Surgery Day is the right occasion to come together and build up the momentum toward the change we desire - to benefit the patient, plastic surgery as a profession, and the welfare of fellow plastic surgeons.

\section{Conflict of Interest \\ None}

\section{References}

1 Thatte M, History of plastic surgery, In: Textbook of plastic, reconstructive and aesthetic surgery, vol I, Principles and advances in plastic surgery. Editors: Agrawal K, Bhattacharya S. P 1-17,Thieme Medical Publishers, Delhi; 2017

2 Sabapathy SR. Genesis of National Plastic surgery day. Available from: https://apsi.in/npsd/Genesis-of-National-Plastic-andReconstructive-Surgery-Day.pdf, Last accessed June 01, 2021.

3 Rohrich RJ, Savetsky IL, Savetsky EB, Avashia YJ. Why Social Media Is Transforming Plastic Surgery. Indian J Plast Surg 2020;53(1):4-5

4 Broer PN, Jenny HE, Ng-Kamstra JS, Juran S. The Role of Plastic Surgeons in Advancing Development Global. World J Plast Surg 2016;5(2):109-113

5 Makhoul AT, Glassman GE, Perdikis G, Nthumba PM, Drolet BC. Characterizing the Global Need for Plastic Surgery Service. Plast Reconstr Surg 2020;146(3):387e-389e

6 Borrelli MR. What Is the Role of Plastic Surgery in Global Health? A Review. World J Plast Surg 2018;7(3):275-282

7 Rakhorst HA, Badran H, Clarke HM, et al. Introducing the International Confederation of Plastic Surgery Societies: ICOPLAST. Plast Reconstr Surg 2017;140(3):627-633 